\title{
The Impact of Knowledge Sharing on the Relationship between Organizational culture and Job Satisfaction: The Perception of Information Communication and Technology (ICT) Practitioners in Hong Kong
}

Canon Tong

International Graduate School of Business, University of Newcastle, Callaghan NSW, Australia

Email: canon.tong@gmail.com

Walder Ip Wah Tak

Newcastle Graduate School of Business, University of Newcastle, Callaghan NSW, Australia Email:walderip@yahoo.com.hk

Anthony Wong

Newcastle Graduate School of Business, University of Newcastle, Callaghan NSW, Australia Email: awong@cihe.edu.hk

Doi:10.5296/ijhrs.v5i1.6895

URL: http://dx.doi.org/10.5296/ijhrs.v5i1.6895

\begin{abstract}
Purpose - The purpose of this article is to analyze the impact of knowledge sharing on the relationship between organizational culture and job satisfaction of ICT industry in Hong Kong so that appropriate strategies can be put in place by relevant decision-makers to enhance corporate performance.

Design/Methodology/Approach - The research includes items of culture dimension, knowledge sharing dimension, job satisfaction dimension and demographic information. Data collected from 228 valid respondents by an internet-based self-administrative anonymous questionnaire survey were analyzed by factor analysis and multiple regressions; validity, reliability and the mediating effect of knowledge sharing were also tested.
\end{abstract}

Findings - Research findings revealed that organizational culture significantly influences 
knowledge sharing and job satisfaction and that knowledge sharing plays an important mediating role between organizational culture and job satisfaction.

Practical Implications - The insightful results provide empirical evidence as potential guidance to employers of ICT industries and management to establish appropriate strategies to retain valuable staff and improve the efficiency of their human resources including incentive and reward policies.

Originality/Value - This research studied the relationships between organizational culture, knowledge sharing and job satisfaction in Hong Kong context since most of the previous studies has focused on western countries. It is unique in that it investigated the mediating effects of knowledge sharing on job satisfaction of ICT practitioners in Hong Kong. The results of this research provide empirical evidence to guide employers and managers towards a collaborative and beneficial organizational culture, enhancement of knowledge sharing practices, and sustainable human resource strategies.

Keywords: Organizational Culture, Knowledge Sharing, Job Satisfaction, China Insurance Industry, Foreign Fund, Challenge

\section{Introduction}

Knowledge sharing is a form of organizational culture management (Fahey and Prusak, 1998). Many studies have found that knowledge sharing is strongly related to organizational culture (Issa and Haddad, 2008; Yang, 2007; Al-Alawi, 2005; Fahey and Prusak, 1998). Job satisfaction, knowledge-sharing attitudes, communication styles, and performance beliefs are correlated (De Vries, Van de Hooff and Ridder, 2006). The foregoing studies suggest that organizational culture, knowledge sharing, and job satisfaction are closely related. Knowledge sharing is defined as activities involved in disseminating or transferring knowledge among individuals, groups or organizations (Lee, 2001), where individuals exchange their tacit and explicit knowledge and create new knowledge (Van den Hooff and De Ridder, 2004). The effectiveness of knowledge-driven work relies on the creation of new knowledge and the sharing of useful existing knowledge through the interaction of tacit and explicit knowledge (Nonaka and Takeuchi, 1995).

Organizational culture refers to the organization's operational process and shared values (Applegate, McFarlan and McKenney, 1999) and represents the norms that guide the attitudes and behavior of the people within an organization (Baumgartner and Zielowski, 2007). Deal and Kennedy (1982) explained that organizational culture may differ according to the role, power structure, ability to manage, and the set of national or regional cultures that top management brings with them to an organization.

Job satisfaction can be defined as pleasantness or unpleasantness of employees while working (Davis, 1988). It reflects how people feel about their jobs in different aspects and is considered to be an indicator of emotional well being (Spector, 1997). Peters and O'Connor (1980) found that job satisfaction is influenced by organizational constraints, and that employees perceiving high levels of constraints tend to be dissatisfied. 
Long and Fahey (2000) revealed that different aspects of organizational culture will influence knowledge-related behaviors. Furthermore, there are limited studies on the job satisfaction of IT professionals (Ghazzawi, 2008). With the increasing importance of and demand for ICT practitioners, there is a need for further study of the impact of knowledge sharing on the relationship between organizational culture and job satisfaction of ICT practitioners. A thorough review of relevant literature revealed that no previous similar research has been carried out on ICT practitioners in Hong Kong.

\subsection{Background of the Study}

Rapid advances in information and communication technology (ICT) have brought a new dimension to daily life through the increasingly important role of personal electronic devices and e-business applications. As industries leverage opportunities for developing services and products by using the latest information technology and telecommunications (IT\&T), there is subsequent increased demand for ICT professionals and knowledge workers in most parts of the developed world; no more so than in Hong Kong (UNCTAD, 2010).

The term ICT is commonly used to cover a board spectrum of industrial and business services such as computer science (CS), information systems (IS), information technology (IT), software engineering (SE), and e-business with both hard skills such as: systems and programming development) and soft skills in communication and interpersonal skills (Litecky, Arnett, and Petrova and Medlin, 2009; Prabhakar, 2004). According to the book "Hong Kong as an Information Society" (Census and Statistics Department, 2009a), ICT industries comprises (i) Manufacturing of IT\&T products; (ii) Communication system installation and maintenance; (iii) Distribution of IT\&T products; (iv) Telecommunications services; and (v) Information technology (IT) services. ICT practitioners refer to the professionals that involve in process, deliver, display information and communicate by electronic means that enable those activities in production of goods and services of ICT or related industries (OECD, 2010; Poulin and Tran, 2010).

New technologies require ICT practitioners to be kept abreast of ICT knowledge. Knowledge sharing is commonly considered as an important element of self-learning and helps the development of professional skills (Wenger and Snyder, 2000). From the operation standpoint, skilful people are still the main drivers of knowledge sharing practice in organizations (Bartol and Srivastava, 2002; Nonaka, 1994). It has also been suggested that companies having the right organizational culture in place to match new technology, will be able to leverage their knowledge capital for an increased competitive advantage (Davenport and Prusak, 1998).

The innovation of smart phones has enabled users to experience new cyber applications and enjoy new forms of instant social communication such as Facebook, Twitter, and YouTube at the touch of a button. The launch of long term evolution technology has also upgraded communication technologies in mobile phones to $4 \mathrm{G}$ (fourth generation). With the advancement of ICT applications, many web-site developers make use of such technologies to develop tools for social media, such as Facebook and Twitter, which is classified as Web 2.0 applications and is widely used by individuals and organizations (Postman, 2009) sharing messages and information visually and interactively. On business operation level, enterprise 
software solutions support business functions and facilitate business strategies to enhance organizational management (Leistner, 2010). For example, Business Intelligence and Business Analytics system provides the support for organizations in the fields of knowledge creation and knowledge discovery as part of knowledge flow management.

Various business applications offer considerable potential for improving operating efficiency and lowering costs. Although most top management believes technology is an important enabler of knowledge flow, many researchers still focus on the human side of enhancing knowledge sharing at work (Leistner, 2010). Ever more people are joining cyberspace as a social network in common with organization network groups that have made knowledge sharing a fundamental social phenomenon (Boer, Baalen, and Kumar, 2002). Therefore, knowing the relationship between organizational culture and knowledge sharing, and how it affects the level of job satisfaction among ICT employees can help companies to retain good employees.

This research examined the impact of knowledge sharing on the relationship between organizational culture and job satisfaction of ICT practitioners in Hong Kong. The four dimension culture model developed by Hofstede (1980), the knowledge sharing model established by De Vries et al., (2006), and the Job Descriptive Index (JDI) developed by Smith, Kendall and Hulin (1969) was used to examine the relevant relationships

\section{Literature Review and Hypotheses Development}

Knowledge is understanding based on experience and belief (Allee, 1997; James, 1907) that encompasses implicit and explicit restrictions placed upon objects, relationships, and operations, along with general or specific heuristics with inferred procedures involved in the situation being modeled (Sowa, 1984). Wiig (1989) defined knowledge as the body of understandings, generalizations, and abstractions that people apply to the management and interpretation of their world. It has also been defined as the information that has been organized and analyzed to make it understandable and applicable to solve problem or to make decision (Turban, 1992).

\subsection{Knowledge Sharing}

Knowledge sharing is considered to be one of the most complex disciplines in knowledge management (Bock and Kim, 2002). It involves the exchange of both explicit and tacit knowledge at the individual, group, and enterprise levels (Small and Sage, 2006) and such exchanging of knowledge contributes to the collective knowledge of an organization (Cabrera and Cabrera, 2002). Knowledge sharing is also defined as the activities of disseminating and transferring knowledge from one person, group, or organization to another (Lee, 2001) requiring the collaboration of individuals and groups for mutual benefits (Al-Alawi, Al-Marzooqi and Mohammed, 2007; Al-Alawi, 2005; Syed-lkhsan and Rowland, 2004). It will help others to improve their self-knowledge if a company has practices that ensure knowledge and its utilisation can be synchronized within it (Öztemel and Arslankaya, 2008).

The global business environment is rapidly becoming more competitive; the traditional 
factors of production on land, labour, and capital have become less relevant to sustain business (Drucker, 1993). The focus of organisations has been drawn to the value of knowledge as a very important economic resource and organisations will be looking to knowledge to provide the means of success (Teece, 1998; Drucker, 1994; Nonaka, 1991). To enhance employee knowledge sharing within organization, Hsu (2006) suggested three approaches, namely: (1) organizational-based approach to simplify knowledge sharing practices by means of appropriate processes, structure, and management style; (2) incentive-based approach to promote knowledge sharing by means of both monetary and non-monetary reward policy; (3) technology-based approach to facilitate knowledge sharing by means of suitable technology and equipment.

To leverage and exchange knowledge and know-how internally and externally, knowledge sharing is recognized as one of the most practical and feasible strategic solutions for technological enterprises faced with the rapidly changing and competitive environment in China (Zahra, Neubaum and Larrañeta, 2007). Unless individual knowledge is effectively shared throughout an organization, it has a very limited impact on the collective knowledge of the organisation (Inkpen, 2000). Van den Hooff and De Ridder (2004) and De Vries et al. (2006) found that knowledge sharing practices can be categorized into two processes: knowledge donating and knowledge collecting. Knowledge donation can be described as an individual's willingness to share his or her intellectual capital and know-how with others. On the other hand, knowledge collection can be described as a person's willingness to consult, adopt and accept new intellectual capital and know-how from his or her colleagues (Lin, 2007; De Vries et al., 2006). People willing to share their knowledge will expect others to reciprocate in the same way for mutual benefit and achieving organizational goals (Lin, 2007; Adler and Kwon, 2002). The willingness and eagerness of individuals to share knowledge is crucial to organizations, as knowledge sharing is not only simple information sharing but is also about stimulating the exchange of thoughts, experiences and ideas amongst individuals within an organization (Ismail, Nor and Marjani, 2009).

\subsection{Organizational Culture}

Trompenaars (1998) considered culture as a framework for groups of people to work within in order to reconcile dilemmas and solves problems, which is manifested at regional or national level. Schein (2004) defined culture as a pattern of shared basic assumptions learned by a group as it solves its problems of internal integration and external adaptation. A relatively recent study by Steers, Sanchez-Runde and Nardon (2010) concluded that culture is shared by members of a group who learn through membership in the group by acquiring assumptions, behaviors and values that influence attitudes and the social behavior of group members. Hofstede (1994) suggested that culture is the collective programming of the human mind that distinguishes members of one human group from another, and that each individual carries patterns of feeling and thinking acquired during childhood that stay with them throughout their life. 
2.3 The Importance of Organizational Culture

Organizational culture is akin to the culture of the society in which the organization operates (Steven, 1989), thus organizational culture can be considered as a micro culture within a given community or nation. Culture is reflected in an organization's norms, value and practices (De Long and Fahey, 2000). Greenberg (2011) claimed that culture plays several important roles in organizations. Firstly, culture generates commitment to an organization's mission; when there is a strong culture; people feel that they are part of a well-defined organization structure. Secondly, culture provides a sense of identity; the more clearly an organization defines its perceptions and values, the more strongly people can associate with its mission and feel a part of it. Thirdly, culture clarifies and reinforces standards of behavior; by guiding employees' words and deeds, the culture provides behavioral stability.

\subsection{Organizational culture and Knowledge Sharing}

Studies on knowledge creation and organizational learning shows that knowledge-sharing activities are strongly influenced by cultural values of individual employees (Jennex, 2006; Hutchings and Michailova, 2004; Hofstede, 2001; Pfeffer and Sutton, 2000), and other research also suggested that the performance of an organization depends on the extent to which the organization's cultural values are shared (Lai and Lee, 2007; De Long and Fahey, 2000). De Long and Fahey (2000) identified four ways that organizational culture influences knowledge-related behaviours: culture defines assumptions about which knowledge is important; it creates the organizational context for social interactions; it mediates the relationships among individual, group, and organizational knowledge; and it impacts the adoption and creation of new knowledge. Ford and Chan (2003) argued that if companies want to gain a competitive advantage through knowledge sharing, an appropriate culture and environment should be in place. Organizational culture has been found not only influencing the successful achievement of knowledge sharing, but also knowledge workers' morale and productivity (Lai and Lee, 2007; Ruppel and Harrington, 2001a; Carayannis, 1998).

Various studies suggested that organizational culture is highly influenced by the national culture of the place in which the organization is located (Jung, Su, Baeza, and Hong, 2008; Lindholm, 2000). Based on an analysis of 88,000 IBM employees in 66 countries, Hofstede (1980) proposed a four component model for measuring organizational culture. They are power distance, uncertainty avoidance, individualism and masculinity. National shared culture could be treated as a pragmatic alternative to analysis at an individual level was supported by Harrison (1994) who argued that even though organizational culture may differ according to the structure, power, role and management style of companies, the set of regional cultures dimensions is nevertheless valid for most organizations. General support for the model has come from Jung et al. (2008), Smith (2002), Dastmalchian, Lee and Ng (2000), Tata and Prasad (1998) and Adler (1997), while Rikowski (2007) affirmed that Hofstede's work on cultural theories is applicable to knowledge management. All things considered, Hofstede's (1980) four component model for measuring organizational culture is clearly the most relevant approach for the purpose of evaluating cultural differences and was therefore adopted for this research. 
Organizational culture is the shared values, beliefs, norms, myths, meanings and assumptions within an organization that also guide employees' behavior toward what is desirable and appropriate. The effects of organizational culture on knowledge sharing have been widely studied (Jennex, 2006; Hutchings and Michailova, 2004; Hofstede, 2001; Pfeffer and Sutton, 2000) and the consensuses appears to be that organizational culture is a critical driver of knowledge sharing. It was therefore hypothesized that:

Hypothesis 1: Knowledge sharing is positively related to organizational culture in Hong Kong's ICT industry.

\subsection{Job Satisfaction}

Researchers have proposed a number of different definitions of job satisfaction over the years; Locke (1976) defined job satisfaction as an individual's positive or negative attitudes towards their job. Mowday, Porter, and Steers (1982) argued that job satisfaction is the relative strength of an individual's identification and involvement in a particular organization. Hodson (1991) defined job satisfaction as the positive feeling that an employee has about his/her job resulting from an evaluation of its characteristics. Greenberg and Baron (2003) considered job satisfaction as an individual's affective, cognitive, and evaluative reactions toward their jobs. In addition to that, it reflects the extent to which people get gratification and the sense of fulfillment that is derived from their job (Griffin and Moorhead, 2007). The term job satisfaction is considered an attribute that exists as the equity of a variety of desired and non-desired job-related experience that fit between the features of a job and employees' expectations (Tutuncu and Kozak, 2007). Finally, George and Jones (2008) stated that job satisfaction is the collection of beliefs and feelings that people have about their current jobs and that people's levels of job satisfaction can be ranged from extreme dissatisfaction to extreme satisfaction.

\subsection{Organizational culture and Job Satisfaction}

Hofstede's (1980) four component culture model provides empirical support for the culture values of particular groups of people (Straub, Loch, Evaristo, Karahanna and Srtie, 2002) as well as for the nature of work that leads to job satisfaction (Mancheno-Smoak, Endres, Potak, and Athanasaw, 2009; Fried and Ferris, 1987).

Organizational culture components comprise variables in relation to organization commitment (Lok and Crawford, 1999) and job satisfaction (Silverthorne, 2004). Trustworthy behavior motivates speedy knowledge sharing communication and a friendly environment increases work performance. Warr (2007) found that happy productive employees exhibit higher levels of performance and find greater job satisfaction. Motivation is strongly related to job satisfaction and job performance and, in some cases, the stimulation by monetary benefits may help (Fichter and Cipolla, 2010; Bassett-Jones and Lloyd, 2005; Mullins, 1996). It was therefore hypothesized that: 
Hypothesis 2: Job satisfaction is positively related to organizational culture in Hong Kong's ICT industry.

\subsection{Knowledge Sharing and Job Satisfaction}

Job satisfaction has a positive relationship with organization commitment (Karatepe and Tekinkus, 2006) and organization commitment has a positive relationship with knowledge sharing (Jacobs and Roodt, 2007), therefore, job satisfaction may has a positive relationship with knowledge sharing (Rehman, Mahmood, Salleh, and Amin, 2010).

The greater the extent of employee involvement in the decision-making process is, the greater the job satisfaction and performance (Tremblay, Sire, and Dalkin, 2000; Witt, Andrews, and Kacmar, 2000). People performing well are more willing and eager to both donate and collect knowledge and helpful in establishing the mechanism to make the group more productive (Hollingshead, 2000; Salancik and Pfeffer, 1977); thus job satisfaction results in positive effects on attitudes, behavior and motivation. To encourage a willingness to share knowledge among teams, organizations should provide a positive corporate culture and trustworthy environment for employees (Inkpen and Tsang, 2005).

Previous literature (Ismail, Nor and Marjani, 2009; Ismail and Yusof, 2008; Lin, 2007; Borgatti and Cross, 2003) identified job satisfaction as a motivational factor that influences knowledge sharing. It has also been found that individuals and group members who enjoy job satisfaction are willing to contribute their knowledge under a friendly environment (Engstrom, 2003) and the increase of individuals' job satisfaction enhances knowledge sharing leading to better team performance (Ismail, Nor and Marjani, 2009; Ismail and Yusof, 2008). Most of the current relevant literature concentrates on multinational corporations and joint ventures, highlighting various factors concerning knowledge sharing including reward systems and organizational culture (Hawamdeh, 2005; Gupta and Govindarajan, 2000b; Simonin, 1999). However, only limited studies consider national cultural factors that influence knowledge sharing (Hutchings and Michailova, 2004; Ford and Chan, 2003).

\subsection{Mediating Construct}

Knowledge sharing comprises two basic activities that consist of active and passive intentions: knowledge donation and knowledge collection (De Vries et al., 2006). Knowledge donation and knowledge collection play a crucial role between the organizational culture and level of job satisfaction within an organization. This research studied the impact of these knowledge-sharing activities on the relationship between organizational culture and job satisfaction. De Vries et al.'s (2006) knowledge sharing model analyses the implementation of knowledge sharing practice in an organization. The literature shows that knowledge sharing is correlated to organizational culture, job satisfaction, trust, social networks, and leadership issues. It was therefore hypothesized that:

Hypothesis 3: Knowledge sharing has a positive mediating effect on the relationship between organisation culture and job satisfaction in Hong Kong's ICT industry. 


\subsection{Research Model}

This research applies Hofstede's (1980) four component culture construct as the independent construct for studying organizational culture in Hong Kong's ICT industry. The main activities of knowledge sharing including knowledge donating and knowledge collecting, identified by De Vries et al. (2006), is mediating construct, The effects of knowledge donating, knowledge collecting and knowledge sharing practices on individual variables and overall organizational culture were tested. Components of job satisfaction were defined as dependent variables affected by organizational culture. Knowledge sharing components were applied as a significant mediator. The conceptual framework of this research is shown as Figure 1 below.

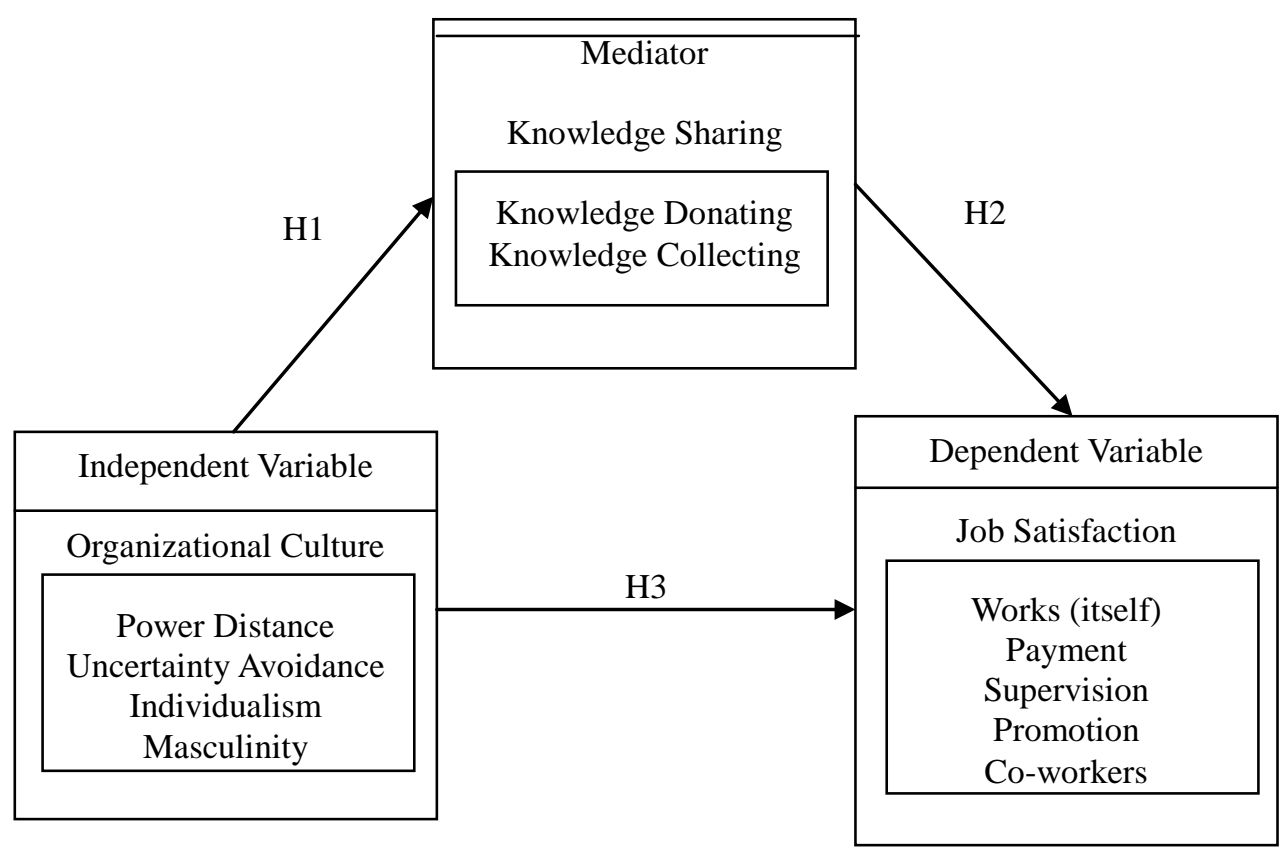

Figure 1 Research Model

\section{Methodology}

This research used a quantitative approach: an internet-based self-administrative anonymous questionnaire survey was conducted to collect data for statistical analysis. Potential participants were randomly selected from ICT-related public websites in Hong Kong.

\subsection{Sample}

Probability sampling was adopted in this research because, as the study was quantitative in nature, a high degree of reliability and generalizability was required (Bryman, 2008; Cavana, Delahaye and Sekaran, 2001). Simple random sampling was chosen, as it contains no division of the population into any different sub-populations in terms of either stratum or clusters and 
so the possibility of classification errors could be eliminated (Bryman, 2008; Malhotra, Hall, Shaw and Oppenheim, 2004; Cavana et al., 2001). One of the main reasons for choosing simple random sampling was to ensure the probability that respondents from different kinds of ICT companies would be selected.

The target population of this research was information communication and technology (ICT) practitioners in Hong Kong. The sample frame of ICT practitioners includes technicians, supervisors, managers, CEO/directors, and company owners with their companies based in Hong Kong. Since the names and email addresses were obtained from public domain, the sample frame could be considered as representative of the population being studied. Random sampling technique was used to ensure potential participants were evenly distributed in the population. Email invitations were sent to 5,000 ICT practitioners randomly selected from ICT- related public websites in Hong Kong.

\subsection{Research Instrument}

The questionnaire comprised of four sections. Sections A, B and C are for collecting data related to organizational culture, knowledge sharing and job satisfaction, whilst section $\mathrm{D}$ is for collecting demographic data of the respondents. The questionnaire adapted sets of previously validated measurement scales from pioneering research (see Appendix A). The invitations emails were sent to invite potential participants within the sample frame to complete a web-based online questionnaire. Questionnaire items of organisation culture were adapted from the four dimensional cultural measurement developed by Hofstede (1980); those of knowledge sharing were adapted from De Vries et al. (2006); and those of job satisfaction were adapted from the widely used five-component (job, supervision, pay, colleagues, and promotion) Job Descriptive Index (JDI), developed by Smith, Kendall and Hulin (1969). Participants were required to voluntarily fill out an online questionnaire. A total of 228 completed returns were received, representing a response rate of $7.6 \%$.

\subsection{Data Analysis}

Collected data was analysed by factor analysis, Pearson Product-Moment Correlation analysis, and regression analysis. Significant variables were tested when there were positive correlations. Factor analysis was used to identify the internal reliability and correlations of variables for each scale. For internal reliability, Cronbach's Alpha technique was used and if the value was greater than 0.7, it was considered to be satisfactory (Nunnally, 1978). Multiple regression analysis was used to test the effect of each hypothesis. If the value of "R Square" is equal to or near to 1 , the hypothesis is critical and significant. Hypotheses were tested at a minimum of 0.05 level of significance. 


\section{Findings}

\subsection{Characteristics of the Sample}

Table 1 summarizes the key demographic variables of the research.

\begin{tabular}{|c|c|c|c|}
\hline Demographic Variables & Measures & Frequency & Percentage \\
\hline \multirow{4}{*}{ Job Position } & Senior Management & 19 & $8.3 \%$ \\
\hline & Middle Management & 81 & $35.6 \%$ \\
\hline & Line Management & 104 & $45.6 \%$ \\
\hline & Operation Staff & 24 & $10.5 \%$ \\
\hline \multirow{6}{*}{ Business Nature } & Manufacturing & 32 & $14.0 \%$ \\
\hline & Installation and Maintenance & 39 & $17.1 \%$ \\
\hline & Distributor & 56 & $24.6 \%$ \\
\hline & Telecom Services & 47 & $20.6 \%$ \\
\hline & IT Services & 42 & $18.4 \%$ \\
\hline & Others & 12 & $5.3 \%$ \\
\hline \multirow[t]{5}{*}{ Size } & $<10$ & 27 & $11.8 \%$ \\
\hline & $11-50$ & 89 & $39.1 \%$ \\
\hline & 51 & -100 & $5021.9 \%$ \\
\hline & $101-200$ & 6 & $2.6 \%$ \\
\hline & $>200$ & 56 & $24.6 \%$ \\
\hline \multirow[t]{5}{*}{ ICT Experiences } & $<2$ years & 13 & $5.7 \%$ \\
\hline & $3-5$ years & 19 & $8.3 \%$ \\
\hline & $6-10$ years & 112 & $49.1 \%$ \\
\hline & $11-20$ years & 66 & $29.0 \%$ \\
\hline & $>20$ years & 18 & $7.9 \%$ \\
\hline \multirow[t]{5}{*}{ Tenure } & $<2$ years & 38 & $16.7 \%$ \\
\hline & $3-5$ years & 80 & $35.1 \%$ \\
\hline & $6-10$ years & 69 & $30.3 \%$ \\
\hline & $11-20$ years & 35 & $15.3 \%$ \\
\hline & $>20$ years & 6 & $2.6 \%$ \\
\hline \multirow[t]{2}{*}{ Gender } & Female & 36 & $15.8 \%$ \\
\hline & Male & 192 & $84.2 \%$ \\
\hline \multirow[t]{5}{*}{$\overline{\text { Age }}$} & $18-24$ & 14 & $6.1 \%$ \\
\hline & $25-34$ & 77 & $33.8 \%$ \\
\hline & $35-44$ & 98 & $43.0 \%$ \\
\hline & $45-54$ & 35 & $15.3 \%$ \\
\hline & $>55$ & 4 & $1.8 \%$ \\
\hline \multirow[t]{2}{*}{ Marital Status } & Single & 84 & $36.8 \%$ \\
\hline & Married & 144 & $63.2 \%$ \\
\hline \multirow[t]{5}{*}{ Education Level } & Secondary & 23 & $10.1 \%$ \\
\hline & Associate Degree/Higher Dipl & oma34 & $14.9 \%$ \\
\hline & Undergraduate & 131 & $57.5 \%$ \\
\hline & Master & 29 & $12.7 \%$ \\
\hline & Doctoral & 11 & $4.8 \%$ \\
\hline \multirow[t]{2}{*}{ Income Level } & $\$ 8000-\$ 15,000$ & 51 & $22.4 \%$ \\
\hline & $\$ 15,001-\$ 28,000$ & 108 & $47.4 \%$ \\
\hline
\end{tabular}




\begin{tabular}{ccr}
\hline$\$ 28,001-\$ 38,000$ & 32 & $14.0 \%$ \\
$\$ 38,001-\$ 50,000$ & 11 & $4.8 \%$ \\
$>\$ 50,000$ & 26 & $11.4 \%$ \\
\hline
\end{tabular}

Table 1 Characteristics of the Sample

\subsection{Factor Analysis and Reliability}

Factor analysis and Cronbach's alpha test were used to assess the validity and reliability of the research. Exploratory factor analysis (EFA) was used to see whether the measuring items were loaded cleanly onto their relevant underlying variables. Cronbach's alpha test was performed to check the reliability of each of the underlying variables by examining the internal consistency of the measuring items loaded onto the variables. All the measuring items were found to be loaded successfully onto one and only one component with a factor loading above 0.4 (Hair, Black, Babin, Anderson and Tatham, 2005). The components were named according to the underlying variables and are shown in Table 2. For organizational culture, the first underlying variable comprised seven measuring items (MS1 to MS7) with a loading weight ranging from 0.695 to 0.809 . As all seven measuring items were related to masculinity, the variable was named "Masculinity". The second underlying variable comprised three measuring items of PD1, PD2 and PD3 with a loading weight ranging from 0.698 to 0.769 . As all three measuring items were related to power distance, the variable was named "Power Distance". The third underlying variable comprised three measuring items (UA1, UA2 and UA3) with a loading weight ranging from 0.710 to 0.824 . As all three measuring items were related to uncertainty avoidance, the variable was named "Uncertainty Avoidance". The last underlying variable comprised seven measuring items (ID1 to ID7) with a loading weight ranging from 0.664 to 0.774 . As all seven measuring items were related to individualism, the variable was named "Individualism". For knowledge sharing, the first underlying variable comprised four measuring items ( $\mathrm{KC} 1$ to $\mathrm{KC} 4)$ with a loading weight ranging from 0.661 to 0.833 . As all four measuring items were related to knowledge collecting, the variable was named "Knowledge Collecting". The second underlying variable comprised four measuring items (KD1 to KD4) with a loading weight ranging from 0.658 to 0.774. As all four measuring items were related to knowledge donating, the variable was named "Knowledge Donating". For job satisfaction, the first underlying variable comprised four measuring items (Job1 to Job4) with a loading weight ranging from 0.727 to 0.844 . As all four measuring items were related to job, hence the variable was named "Job". The second underlying variable comprised five measuring items (Pay1 to Pay5) with a loading weight ranging from 0.771 to 0.816 . As all five measuring items were related to pay, the variable was named "Pay". The third underlying variable comprised six measuring items (Sup1 to Sup6) with a loading weight ranging from 0.721 to 0.801 . As all six measuring items were related to supervisors of respondents, the variable was named "Supervisors". The fourth underlying variable comprised six measuring items (Col1 to Col6) with a loading weight ranging from 0.721 to 0.794 . As all six measuring items were related to colleagues of the respondents, the variable was named "Colleagues". The last underlying variable comprised five measuring items (Pro1 to Pro5) with a loading weight ranging from 0.718 to 0.810 . As all five measuring items were related to promotion, the variable was named "Promotion". 


\section{Macrothink Institute ${ }^{\mathrm{TM}}$}

Cronbach's alpha tests were performed to gauge the reliability of the 11 underlying variables by measuring their respective levels of consistency among the measuring items loaded onto the variables (Hair et al., 2005). Table 2 below reveals that all 11 variables with a Cronbach's alpha value ranging from 0.719 to 0.884 , all of them were higher than 0.7 , suggesting that all underlying variables were having an acceptable internal consistency for further analysis (Hair et al., 2005).

\begin{tabular}{|c|c|c|}
\hline Item Description & Factor Loading & Cronbach's Alpha \\
\hline Masculinity & & 0.884 \\
\hline MS1 & 0.772 & \\
\hline MS2 & 0.724 & \\
\hline MS3 & 0.788 & \\
\hline MS4 & 0.726 & \\
\hline MS5 & 0.695 & \\
\hline MS6 & 0.768 & \\
\hline MS7 & 0.809 & \\
\hline Power Distance & & 0.719 \\
\hline PD1 & 0.756 & \\
\hline PD2 & 0.698 & \\
\hline PD3 & 0.769 & \\
\hline Uncertainty Avoidance & & 0.738 \\
\hline UA1 & 0.710 & \\
\hline UA2 & 0.824 & \\
\hline UA3 & 0.787 & \\
\hline Individualism & & 0.847 \\
\hline ID1 & 0.706 & \\
\hline ID2 & 0.706 & \\
\hline ID3 & 0.692 & \\
\hline ID4 & 0.690 & \\
\hline ID5 & 0.706 & \\
\hline ID6 & 0.664 & \\
\hline ID7 & 0.774 & \\
\hline Knowledge Donating & & 0.800 \\
\hline KD1 & 0.727 & \\
\hline KD2 & 0.774 & \\
\hline KD3 & 0.727 & \\
\hline KD4 & 0.658 & \\
\hline Knowledge Collecting & & 0.795 \\
\hline $\mathrm{KC} 1$ & 0.833 & \\
\hline $\mathrm{KC} 2$ & 0.676 & \\
\hline $\mathrm{KC} 3$ & 0.753 & \\
\hline $\mathrm{KC4}$ & 0.661 & \\
\hline Job & & 0.796 \\
\hline Job1 & 0.844 & \\
\hline Job2 & 0.753 & \\
\hline Job3 & 0.766 & \\
\hline Job4 & 0.727 & \\
\hline
\end{tabular}




\begin{tabular}{ccc}
\hline Pay1 & 0.816 & \\
Pay2 & 0.780 & \\
Pay3 & 0.814 & \\
Pay4 & 0.771 & 0.878 \\
Pay5 & 0.788 & \\
\hline Supervisors & & \\
Sup1 & 0.780 & \\
Sup2 & 0.770 & \\
Sup3 & 0.721 & \\
Sup4 & 0.758 & \\
Sup5 & 0.801 & \\
Sup6 & 0.781 & \\
Colleagues & & \\
Col1 & 0.724 & \\
Co12 & 0.766 & \\
Col3 & 0.759 & \\
Col4 & 0.728 & \\
Col5 & 0.794 & \\
Col6 & 0.775 & \\
\hline Promotion & & \\
Pro1 & 0.791 & \\
Pro2 & 0.767 & \\
Pro3 & 0.810 & \\
Pro4 & 0.755 & \\
\hline
\end{tabular}

Table 2 Factor Loading and Reliability

\subsection{Hypotheses Testing}

The three hypotheses of this research were tested by using multiple regression analysis.

\subsubsection{The Influence of Organisation Culture on Knowledge Sharing}

Table 3 below shows the coefficient for testing hypothesis 1 that knowledge sharing is positively related to organisation culture in Hong Kong's ICT industry. The multiple regression test produces a standardized Beta value of $0.320(\mathrm{~F}=10.279 ; \mathrm{p}=0.000)$, confirming that organizational culture affected knowledge sharing and hence hypothesis 1 was supported.

\begin{tabular}{|l|c|c|c|}
\hline Independent Variable & Standardized Beta & F & Sig. \\
\hline Organizational Culture & 0.320 & 10.279 & 0.000 \\
\hline
\end{tabular}

Dependent Variable: Knowledge Sharing

Table 3 Coefficient of Hypothesis 1

\subsubsection{The Influence of Organisation Culture on Job Satisfaction}

Table 4 shows the coefficient for testing hypothesis 2 that job satisfaction is positively related to organisation culture in Hong Kong's ICT industry. The multiple regression test produces a 
standardized Beta value of $0.286(\mathrm{~F}=3.683 ; \mathrm{p}=0.000)$, confirming that organizational culture affects job satisfaction and hence hypothesis 2 was supported.

\begin{tabular}{|l|c|c|c|}
\hline Independent Variable & Standardized Beta & F & Sig. \\
\hline Organizational culture & 0.286 & 3.683 & 0.000 \\
\hline
\end{tabular}

Dependent Variable: Job Satisfaction

Table 4 Coefficient of Hypothesis 2

\subsubsection{The Mediating Role of Knowledge Sharing}

Multiple regression analysis was used in testing hypothesis 3 that knowledge sharing has a positive mediating effect on the relationship between organizational culture and job satisfaction in Hong Kong's ICT industry. Multiple regression approach for testing mediating effects developed by Judd and Kenny (1981) and Baron and Kenny's (1986) was adopted. The hypotheses tested in Sections 4.3.1 and Section 4.3.2 above confirm that organizational culture (the hypothesized independent variable) exerts positive and significant influences on both job satisfaction (the hypothesized dependent variable) and knowledge sharing (the hypothesized mediator). Therefore, the pre-requirements of the mediating effect test posited by Judd and Kenny (1981) were met.

The difference between the levels of influence of organizational culture on job satisfaction, with and without the presence of knowledge sharing, was used to calculate the mediating effect (Baron and Kenny, 1986). Three regression models were applied in the procedure: the first model calculated the influence of the control variable; the second model, with the addition of organizational culture, calculated the direct influence of organizational culture on job satisfaction; and the third model, with the addition of both organizational culture and knowledge sharing, calculated the direct influence of organizational culture on job satisfaction in the presence of knowledge sharing.

Tables 5 and 6 below present the results of the multiple regression tests on the three models. In model 1, the following ten control variables were included: job position, experience in the ICT field, tenure, gender, age, marital status, education level, income level, business nature, and firm size (measured by number of employees). In model 2, organizational culture was added and in model 3 both organizational culture and knowledge sharing were added.

\begin{tabular}{|ll|c|c|c|c|c|}
\hline \multirow{2}{*}{ Model } & \multicolumn{2}{|c|}{$\begin{array}{c}\text { Un-standardized } \\
\text { Coefficients }\end{array}$} & $\begin{array}{c}\text { Standardized } \\
\text { Coefficients }\end{array}$ & \multicolumn{2}{|c|}{} \\
\cline { 2 - 7 } & $\mathrm{B}$ & Std. Error & Beta & $\mathrm{t}$ & Sig. \\
\hline 1 & (Constant) & -.865 & .745 & & -1.162 & .247 \\
& Position & .052 & .120 & .041 & .436 & .663 \\
& BusNature & -.014 & .049 & -.020 & -.280 & .780 \\
& Employees & -.061 & .057 & -.083 & -1.063 & .289 \\
& Experience & -.093 & .086 & -.086 & -1.081 & .281
\end{tabular}




\begin{tabular}{|c|c|c|c|c|c|c|}
\hline & Tenure & .115 & .077 & .118 & 1.506 & .134 \\
\hline & Gender & .127 & .194 & .046 & .653 & .515 \\
\hline & Age & -.165 & .102 & -.141 & -1.620 & .107 \\
\hline & Marital & .366 & .155 & .177 & 2.359 & .019 \\
\hline & Education & .128 & .093 & .118 & 1.368 & .173 \\
\hline & Income & .064 & .092 & .078 & .696 & .487 \\
\hline 2 & (Constant) & -.525 & .718 & & -.730 & .466 \\
\hline & Position & .008 & .115 & .006 & .068 & .946 \\
\hline & BusNature & -.010 & .047 & -.014 & -.208 & .835 \\
\hline & Employees & -.045 & .055 & -.061 & -.807 & .421 \\
\hline & Experience & -.077 & .083 & -.072 & -.936 & .350 \\
\hline & Tenure & .096 & .074 & .099 & 1.309 & .192 \\
\hline & Gender & .123 & .186 & .045 & .664 & .508 \\
\hline & Age & -.169 & .098 & -.145 & -1.728 & .085 \\
\hline & Marital & .286 & .150 & .138 & 1.907 & .058 \\
\hline & Education & .071 & .091 & .065 & .780 & .436 \\
\hline & Income & .071 & .089 & .086 & .798 & .426 \\
\hline & Organizational Culture & .286 & .064 & .286 & 4.441 & .000 \\
\hline 3 & (Constant) & -.650 & .667 & & -.974 & .331 \\
\hline & Position & .063 & .107 & .050 & .587 & .558 \\
\hline & BusNature & .004 & .044 & .006 & .094 & .925 \\
\hline & Employees & -.020 & .051 & -.027 & -.391 & .696 \\
\hline & Experience & -.084 & .077 & -.077 & -1.091 & .277 \\
\hline & Tenure & .121 & .068 & .124 & 1.771 & .078 \\
\hline & Gender & .068 & .173 & .025 & .395 & .693 \\
\hline & Age & .035 & .097 & .030 & .365 & .716 \\
\hline & Marital & .064 & .144 & .031 & .445 & .657 \\
\hline & Education & .002 & .085 & .002 & .022 & .983 \\
\hline & Income & .049 & .082 & .060 & .601 & .548 \\
\hline & Organizational Culture & .149 & .064 & .149 & 2.327 & .021 \\
\hline & Knowledge Sharing & .429 & .071 & .429 & 6.001 & .000 \\
\hline
\end{tabular}

Table 5 Coefficients - Mediating Role of Knowledge Sharing (3)

The Model Coefficients presented in Table 5 illustrates that in model 2 (i.e. in the absence of the mediator of knowledge sharing), the standardized beta coefficient for the path between organizational culture and job satisfaction was 0.286 and significant $(t=4.441 ; t=0.000)$. In model 3, by adding the mediator, knowledge sharing, the standardized beta coefficient for the path between organizational culture and job satisfaction reduced to 0.149 and was significant 
$(\mathrm{t}=2.327 ; \mathrm{t}=0.021)$. The strength of the mediating effect was 0.137 , which was the difference between 0.286 in model 2 and 0.149 in model 3 (Judd and Kenny, 1981). As shown in Table 6, the explanation power of model 2 was $11.5 \%$ (Adjusted R Square $=0.115$; $\mathrm{R}$ Square Change $=0.077 ; \mathrm{F}=19.724 ; \mathrm{df} 1=1 ; \mathrm{df} 2=216 ; \mathrm{p}=0.000)$; by adding the mediator of knowledge sharing, the explanation power (model 3) of the regression model increased by $12.1 \%$ ( $\mathrm{R}$ Square Change $=0.121 ; \mathrm{F}=36.007$, df1 $=1 ; \mathrm{df} 2=215 ; \mathrm{p}=0.000$ ) to $23.8 \%$ (Adjusted R Square $=0.238$ ).

\begin{tabular}{|c|c|c|c|c|c|c|c|c|c|}
\hline \multirow[b]{2}{*}{ Model } & \multirow[b]{2}{*}{$\mathrm{R}$} & \multirow[b]{2}{*}{$\begin{array}{c}\mathrm{R} \\
\text { Square }\end{array}$} & \multirow[b]{2}{*}{$\begin{array}{c}\text { Adjuste } \\
\text { d R } \\
\text { Square }\end{array}$} & \multirow[b]{2}{*}{$\begin{array}{l}\text { Std. Error } \\
\text { of the } \\
\text { Estimate }\end{array}$} & \multicolumn{5}{|c|}{ Change Statistics } \\
\hline & & & & & $\begin{array}{c}\text { R Square } \\
\text { Change }\end{array}$ & $\begin{array}{c}\text { F } \\
\text { Chang } \\
\text { e }\end{array}$ & df1 & df2 & $\begin{array}{c}\text { Sig. F } \\
\text { Change }\end{array}$ \\
\hline 1 & $.285^{\mathrm{a}}$ & .081 & .039 & .98047065 & .081 & 1.913 & 10 & 217 & .045 \\
\hline 2 & $.397^{\mathrm{b}}$ & .158 & .115 & .94072483 & .077 & 19.724 & 1 & 216 & .000 \\
\hline 3 & $.528^{\mathrm{c}}$ & .279 & .238 & .87266386 & .121 & 36.007 & 1 & 215 & .000 \\
\hline
\end{tabular}

a. Predictors: (Constant), Income, Gender, BusNature, Tenure, Marital, Employees, Experience, Education, Age, Position

b. Predictors: (Constant), Income, Gender, BusNature, Tenure, Marital, Employees, Experience, Education, Age, Position, Organizational Culture

c. Predictors: (Constant), Income, Gender, BusNature, Tenure, Marital, Employees, Experience, Education, Age, Position, Organizational Culture, Knowledge Sharing

Table 6 Model Summary - Mediating Role of Knowledge Sharing

Although both the strength and the significance level of the influence of organizational culture on job satisfaction were reduced (level of influence reduced from 0.286 to 0.149 ; significance level reduced from $\mathrm{p}=0.000$ to $\mathrm{p}=0.021$ ), the influence remained significant; therefore, hypothesis 3 was partially supported. In other words, knowledge sharing partially mediated the influence of organizational culture on job satisfaction.

\section{Discussion}

The aim of this research was to examine the interrelationship among the components of organizational culture, knowledge sharing, and job satisfaction. Using ICT practitioners in Hong Kong as the key elements, the study took measured their perceptions with respect to each of the components.

The demographic data of this research showed a much higher percentage of male respondents. It may be a reflection of male dominance in ICT industries. The two major age groups, 25 to 34 and 35 to 44, indicate that they believe knowledge sharing benefit them to improve work efficiency (Ba, Stallaert, and Whinston, 2001). The research findings revealed that most of the firms were either SMEs or larger companies. Regarding ICT experience of the respondents, nearly half of the respondents had less than 10 years ICT experience and about one-third of them served with the same company for 6-10 years. This indicates that the turnover of ICT practitioner is generally less than 10 years. Dissatisfaction with the job itself, with pay, with supervisors, with colleagues, or with a lack of promotion prospects could be 
the reasons for not staying with a firm longer. Together with the high level of education with undergraduate degree and associate degree or higher diploma suggests that ICT companies should recruit people with more ICT experience and with high-level educational or professional qualifications such as e-skill, e-learning, and e-business.

Results of prior study suggest that organizational culture impacted knowledge sharing practices. In this research, regression models were used to test the same assumption in the ICT sector which confirmed that knowledge sharing is positively related to organizational culture. The results also suggest that organizational culture impact job satisfaction. Once again, regression models were used to test hypothesis 2 which confirmed that job satisfaction is positively related to organizational culture.

Hypothesis testing led to the findings that the effects of organizational culture on job satisfaction were mainly caused by the strong and significant indirect effect of 0.583 ( $\mathrm{p}=$ 0.008) exerted by knowledge sharing, while the direct effect of organizational culture on job satisfaction was only 0.140 and insignificant $(p=0.0708)$ if the knowledge sharing factor was not included. This revealed that knowledge sharing partially mediates the influence of organizational culture on job satisfaction.

Although both the strength and the significance level of the influence of organizational culture on job satisfaction were reduced (level of influence reduced from 0.286 to 0.149 ; significance level reduced from $p=0.000$ to $p=0.021$ ), the influence remained significant; therefore, hypothesis 3 was partially supported. The overall results that knowledge sharing has a positive mediating effect on the relationship between organizational culture and job satisfaction in Hong Kong's ICT industry.

\section{Implications}

This research provides a better understanding of the expectation of ICT practitioners in Hong Kong for both commercial and academic purposes. Evidence from the research suggests that top management and human resources managers need to cultivate an organizational culture that encourages knowledge-sharing practices that will ultimately benefit both organizations and employees, and improve overall job satisfaction. The results also reveal the framework for the business implications on strategy formulation and academic contributions on strategy appropriateness and other managerial variables may be added if being needed for further studies.

\subsection{Management Implications}

The implications of the research results for management and business is that it is imperative that ICT organizations in Hong Kong promote a knowledge sharing culture in order to ensure the continued success of their companies and enhance the job satisfaction of their employees. The variables used in the research could provide guidance to employers in Hong Kong's ICT industry as to how they might both retain and recruit ICT practitioners and other similarly qualified and skilled staff. This research provides a better understanding of the relationships among organizational culture, knowledge sharing and job satisfaction among ICT sector in Hong Kong. The results will help decision-makers in Hong Kong's ICT industry and the 
Hong Kong government to establish appropriate strategies to retain valuable employee and improve the efficiency of their human resources.

The research reveals that the relationships between organizational culture and job satisfaction and that knowledge sharing has a strong mediating effect on both of the two factors that provide a clue regarding how firms can promote a sustained knowledge sharing culture. The findings draw the attention to organization theory and are especially concerned with the interplay between the creation and exchange of knowledge, and how to align the development of organizational forms with social relationships when knowledge sharing activities take place. It also highlights the distinction between practices to manage knowledge acquisition, knowledge exchange and re-use, and knowledge creation. Strategies for increasing the effectiveness of knowledge re-use and creation should be aligned with the company's value. To achieve this, sharing knowledge should be linked to solving practical business problems and tied to a pre-existing core value mechanism. Peers and supervisors should be encouraged to share knowledge by structuring incentive and reward policies that acknowledge the importance of knowledge sharing.

The findings of this research also confirm the direct positive effects of organizational culture on knowledge sharing and job satisfaction that ultimately leads to an improvement in organization performance. Organization performance is considered as case specific and decision-maker specific (Lebas, 1995) and organizational culture is a major factor that determines knowledge sharing practices. IT systems that capture, store, and improve access to knowledge should be accompanied by a favourable environment to support, energize, mobilize, and enable people at all levels to the best utilize the company's available resources.

Knowledge sharing activities, being under the umbrella of knowledge management, should be strategized by human resource professionals who should introduce learning programs and necessary change to ensure resource maximization. They should inform their colleagues of the importance of organizational factors that occur in knowledge management, provide related training programs, identify specific cultural creativity, encourage knowledge processes, and help build up features conducive to knowledge sharing (Evans, 2003).

This research makes direct links between organizational culture, knowledge sharing, and job satisfaction, all of which contribute to a company's increased competitiveness. The research model developed for this research is able to provide a framework for measuring similar research that examines the antecedents and consequences of employees' level of job satisfaction.

Leadership is the key to encouraging employee involvement in knowledge sharing. Missions should be structured to identify achievable strategic goals, and consistent planning should be made by developing a sense of belonging so that concentrated efforts could bring those goals into reality. It is incumbent upon human resources practitioners to become strategic partners and work in alliance with other employees to implement strategy (Ulrich, 1998; Torraco and Swanson, 1996).

The results pinpoint several aspects of strategy that are favourable to the development of 
knowledge: an analytical attitude to business issues, an orientation to organizational culture and knowledge sharing practices, a clear outlook to the future, and a proactive approach. By focusing on the four aspects of strategy, HR professionals could help their organizations develop awareness of the strategic areas that can facilitate a friendly knowledge sharing atmosphere, as well as knowledge management effectiveness. Further, ICT practitioners could be more proactive in helping develop the necessary collaborative strategic directions, according to their companies' resources, for the generation and distribution of knowledge based on the framework developed for this research.

\subsection{Academic Contributions}

First, the research produced a research model for empirical research that describes and predicts the effects of organizational culture and knowledge sharing on job satisfaction based on the perception of ICT practitioners in Hong Kong. It includes the results of previous relevant studies as support and justification for the investigation carried out by this study.

Second, the research provides a research framework for practitioners and researchers in other jurisdictions who wish to carry out related research. Organizational culture factors (Hofstede, 1980), knowledge sharing factors (De Vries et al., 2006), and job satisfaction factors (Smith, Kendall and Hulin, 1969) were used to study the direct effect of organizational culture on knowledge sharing and job satisfaction, and the mediating effect of knowledge sharing on the relationship between organizational culture and job satisfaction. Since this triangular inter-cross framework was especially developed for this research and had never before been applied, its use in the Hong Kong context proved it suitability for such a study.

Third, the research adopted three valid constructs that can be used as a reference for further studies. In this study, structural equation modelling in a comprehensive two-step modelling approach with a series of nested models, sequential chi-square tests, and confirmatory factor analysis were used for theory testing. Structural equation modelling was used to confirm the research model and verify the findings from multiple regression tests (Judd and Kenny, 1981), while Baron and Kenny's (1986) mediating procedure proved to be a satisfactory mediating testing tool as alternative to the Pearson product-moment correlation test.

Finally, by providing reliable measurements that can be used to analyse the attitude of employees to knowledge sharing and job satisfaction, this study makes a significant contribution to the existing body of knowledge in the field of knowledge management and provides a sound basis for further relevant research.

\section{Limitations and Future Research}

This research used quantitative methodology to examine the relationships among organizational culture, knowledge sharing and job satisfaction. It is possible that there may be other variables that affect or moderate the hypothesized relationship. Further studies, which employ both quantitative and qualitative approaches, can be conducted to explore other possible relationships.

The research may also be limited in terms of its generalizability since the findings were based 
on the perceptions of ICT practitioners in Hong Kong, the culturally specific and sector-specific sample may affect the applicability of the implications discussed to other fields, cultures or geographical locations. Further studies should be conducted to ascertain how generalizable the findings would be to other settings or practitioners in other sectors.

Another limitation of the research relates to the research finding is that the mediator of knowledge sharing exerted no influence on the relationship between organizational culture and job satisfaction. This finding suggests that other factors might be involved. To address this issue, further study using a mixed approach research can be conducted to take advantage of triangulation. Qualitative research techniques and a large-scale empirical study using quantitative methods may be conducted to collect data from a wider population. Again qualitative research is then followed to confirm the findings from the quantitative empirical study in order to obtain a more precise and comprehensive picture.

Finally, the cross-sectional nature of this research confines the study to snapshot statistical relationships without taking into account the possible changes in perception over time. Just as it takes a long time for a business to grow, time is needed for developing appropriate organizational culture and knowledge sharing practices to impact employees' job satisfaction. A longitudinal approach, which addresses the time lag between cause and effect may enhance understanding of the casual relationships and help determine if there are any other contributing factors.

\section{References}

Adler, N. J. (1997) International dimensions of organizational behavior, Southwestern, Cincinnati, $\mathrm{OH}$.

Adler, S. P. and Kwon, S. W. (2002) Social capital: prospects for a new concept, Academy of Management Review, 27, 1, pp. 17-40.

Al-Alawi, A. I. (2005) The practice and challenges of knowledge management in financial sectors in Bahrain, Asian Journal of Information Systems, 4, 1, pp. 101-107.

Al-Alawi, A. I., Al-Marzooqi, N. Y. and Mohammed, Y. F. (2007) Organizational culture and knowledge sharing: critical success factors, Journal of Knowledge Management, 11, 2, pp. 22-42.

Allee, V. (1997) The knowledge evolution: expanding organizational intelligence, Butterworth-Heinemann, Boston, MA.

Applegate, L. M., McFarlan, F. W. and McKenney, J. L. (1999) Corporate information systems management, Irwin McGraw-Hill, Boston, MA.

Ba, S., Stallaert, J. and Whinston, A. B. (2001) Research commentary: introducing a third dimension in information systems design - the case of incentive alignment, Information systems research, 12, 3, pp. 225-239. 
Baron, R. M. and Kenny, D. A. (1986) The moderator-mediator variable distinction in social psychological research: conceptual, strategic, and statistical considerations, Journal of Personality and Social Psychology, 51, 6, pp.1173-1182.

Bartol, K. M. and Srivastava, A. (2002) Encouraging knowledge sharing: the role of organizational reward systems, Journal of Leadership and Organization Studies, 9, 1, pp. 64-76.

Bassett-Jones, N. and Lloyd, C. (2005) Does Herzberg's motivation theory have staying power? The Journal of Management Development, 24, 10, pp. 929-943.

Baumgartner, R. J. and Zielowski, C. (2007) Analyzing zero emission strategies regarding impact on organisation culture and contribution to sustainable development, Journal of Cleaner Production, 15, 13/14, pp. 1321-1327.

Borgatti, S. P. and Cross, R. (2003) A relational view of information seeking and learning in social networks, Management Science, 49, pp. 432-445.

Bock, G. W. and Kim, Y. G. (2002) Breaking the myths of rewards: an exploratory study of attitudes about knowledge sharing, Information Resources Management Journal, 15, 2, pp. 14-21.

Boer, N., van Baalen, P. J. and Kumar, K. (2002) The importance of sociality for understanding knowledge sharing processes in organizational contexts, ERIM Report Series Research in Management, Rotterdam Erasmus Research Institute of Management (ERIM).

Borgatti, S. P. and Cross, R. (2003) A relational view of information seeking and learning in social networks, Management Science, 49, pp. 432-445.

Bryman, A. (2008) Social research methods, $3^{\text {rd }}$ ed., Oxford University Press, Oxford.

Cabrera, A. and Cabrera, E. F. (2002) Knowledge-sharing dilemmas, Organization Studies, 23, 5, pp. 687-710.

Carayannis, E. G. (1998) The strategic management of technology learning in project/program management: the role of extranets, intranets and intelligent agents knowledge generation, diffusion and leveraging, Technovation, 18, 11, pp. 697-703.

Cavana, R. Y., Delahaye, B. L. and Sekaran, U. (2001) Applied business research: qualitative and quantitative methods, Milton, Queensland: John Wiley \& Sons.

Census and Statistics Department (2009a) Hong Kong as an information society, HKSAR.

Dastmalchian, A., Lee, S. and Ng, I. (2000) The interplay between organizational and national cultures a comparison of organizational practices in Canada and South Korea using the competing values framework, International Journal of Human Resource Management, 11, 2, pp. 388-412.

Davenport, T. H. and Prusak, L. (1998) Working Knowledge: How organizations manage 
what they know, Harvard Business School Press, Boston, MA.

Davis, K. (1988) Human behaviour at work: organisational behaviour, $5^{\text {th }}$ ed., McGraw-Hill, New York.

De Long, D. W. and Fahey, L. (2000) Diagnosing cultural barriers to knowledge management, Academy of Management Executive, 14, 4, pp. 113-127

De Vries, R. E., Van den Hoff, B. and de Ridder, J. A. (2006) Explaining knowledge sharing: the role of team communication styles, job satisfaction, and performance beliefs, Communication Research, 33, 2, pp. 115-135.

Deal, T. E. and Kennedy, A. A. (1982) Corporate cultures: the rights and rituals of corporate life, Addison-Wesley, Reading, MA.

Drucker, P. F. (1993) Post-Capitalist Society, Butterworth-Heinemann, Oxford.

Drucker, P. F. (1994) The theory of the business, Harvard Business Review, 72, 5, pp. 95-104.

Engstrom, T. E. J. (2003) Sharing knowledge through mentoring, Performance Improvement, 42, 8, pp. 36-42.

Evans, C. (2003) Managing for knowledge: HR's strategic role, Butterworth-Heinemann, Amsterdam.

Fahey, L. and Prusak, L. (1998) The eleven deadliest sins of knowledge management, California Management Review, 40, 3, pp. 265-276.

Fichter, C. and Cipolla, J. (2010) Role conflict, role ambiguity, job satisfaction, and burnout among financial advisors, Journal of American Academy of Business, 15, 2, pp. 256-261.

Ford, D. P. and Chan, Y. E. (2003) Knowledge sharing in multi-cultural setting: a case study, Knowledge management Research and Practice, 1, 1, pp. 11-27.

Fried, Y. C. and Ferris, G. R. (1987) The validity of the job characteristics model: a review and meta-analysis, Personnel Psychology, 40, pp. 287-322.

George, J. M. and Jones, G. R. (2008) Understanding and managing organizational behavior, $5^{\text {th }}$ ed., Pearson Prentice-Hall, Upper Saddle River, NJ.

Ghazzawi, I. A. (2008) Job satisfaction among information technology professionals in the U.S.: an empirical study, Journal of American Academy of Business, 13, 1, pp. 1-15.

Greenberg, J. (2011) Behavior in organizations, $10^{\text {th }}$ ed., Prentice Hall, Upper Saddle River, NJ.

Greenberg, J. and Baron, R.A. (2003) Behavior in organizations: understanding and managing the human side of work, $18^{\text {th }}$ ed., Prentice-Hall, New Jersey.

Griffin, R. and Moorhead, G. (2007) Organizational behavior: managing people and organizations, $18^{\text {th }}$ ed., Houghton Mifflin Company, Boston, MA. 
Gupta, A. K. and Godvindarajan, V. (2000b) Knowledge flows within multinational corporations, Strategic Management Journal, 21, pp. 473-496.

Hair, J. F., Black, B., Babin, B., Anderson, R. E. and Tatham, R. L. (2005) Multivariate Data Analysis, $4^{\text {th }}$ ed., Prentice Hall, Upper Saddle River, N.J.

Harrison, G. (1994) Culture and management, Australian Accountant, 64, 10, pp. 14-22.

Hawamdeh, S. (2005) Knowledge management: nurturing culture, innovation and technology, World Scientific Publishing Co, Hackensack, NJ.

Hodson, R. (1991) Workplace behaviors, Work and Occupations, August, pp. 271-290.

Hofstede, G. H. (1980) Culture's consequences: international differences in work-related attitudes, Sage Publications, Thousand Oaks, CA.

Hofstede, G. H. (1994) Cultures and organizations: software of the mind: intercultural cooperation and its importance for survival, Harper Collins, London.

Hofstede, G. H. (2001) Culture's consequences: comparing values, behaviors, institutions and organizations across nations, $2^{\text {nd }}$ ed., Sage Publications, Thousand Oaks, CA.

Hollingshead, A. B. (2000) Perceptions of experience and transactive memory in work relationship, Group Processes \& Intergroup Relation, 3, pp. 257-267.

Holsapple, C. W. and Joshi, K. D. (2001) An investigation of factors that influence the management of knowledge in organizations, Journal of Strategic Information Systems, 9, 2-3, pp. 235-261.

Hsu, I. C. (2006) Enhancing employee tendencies to share knowledge - case studies of nine companies in Taiwan, International Journal of Information Management, 26, 4, pp. 326- 338 .

Hutchings, K. and Michailova, S. (2004) Facilitating knowledge sharing in Russian and Chinese subsidiaries: the role of personal networks and group membership, Journal of Knowledge Management, 8, 2, pp. 84-94.

Inkpen, A. C. (2000) Learning through joint ventures: a framework of knowledge acquisition, Journal of Management Studies, 37, 7, pp. 1019-1043.

Inkpen, A. C. and Tsang, E. W. (2005) Social capital networks, and knowledge transfer, Academy of Management Review, 30, 1, pp. 146-165.

Ismail, M. B. and Yusof, Z. M. (2008) Factors affecting knowledge sharing in public organizations in Malaysia. Proceedings of 2008 Knowledge Management International Conference, 10-12 June, Langkawi, Malaysia, viewed 12 Dec, 2011. http://www.kmice.uum.edu.my/kmice08/Paper/CR96.do

Ismail, W. K., Nor, K. M. and Marjani, T. (2009) The role of knowledge sharing practice in 
enhancing project success, Interdisciplinary Journal of Contemporary Research In Business, 1, 7, pp. 34-52.

Issa, R. A. A. and Haddad, J. (2008), Perceptions of the impacts of organisational culture and information technology on knowledge sharing in construction, Construction Innovation, 8, 3, pp. 182-201.

Jacobs, E. and Roodt, G. (2007) The development of a knowledge sharing construct to predict turnover intentions, Aslib Proc., 59, pp. 229-248

James, W. (1907), Pragmatism, Longmans, New York.

Jennex, M. E. (2006) Culture, context, and knowledge management, International Journal of Knowledge Management, 2, 2, pp.1-4.

Judd, C. M. and Kenny, D. A. (1981) Process analysis: estimating mediation in treatment evaluations, Evaluation Review, 5, pp. 602-619

Jung, J., Su, X., Baeza, M. and Hong, S. (2008) The effect of organizational culture stemming from national culture towards quality management deployment, The TQM Magazine, 20, 6, pp. 622-635.

Karatepe, O. and Tekinkus, G. (2006) The effects of work-family conflict, emotional exhaustion, and intrinsic motivation on job outcomes of front-line employees, International Journal of Bank Marketing, 24, 3, pp. 173-193.

Lai, M. F. and Lee, G. G. (2007) Risk-avoiding cultures toward achievement of knowledge sharing, Business Process Management Journal, 13, 4, pp. 522-527.

Lebas, M. J. (1995) Performance measurement and performance management, International Journal of Production Economics, 41, 1, pp. 23-35.

Lee, J. N. (2001) The impact of knowledge sharing, organizational capability and partnership quality on IS outsourcing success, Information \& Management, 38, 5, pp. 323-335.

Leistner, F. (2010) Mastering organizational knowledge flow: how to make knowledge sharing work, John Wiley \& Sons, Inc., Hoboken, N.J.

Lin, H.F. (2007) Knowledge sharing and firm innovation capability: an empirical study, International Journal of Manpower, 28, 3-4, pp. 315-332.

Lindholm, N. (2000) National culture and performance management in MNC subsidiaries, International Studies of Management \& Organization, 29, 4, pp.45-66.

Litecky, C. R., Arnett, K. P. and Prabhakar, B. (2004) The paradox of soft skills vs. technical skill in IShiring, Journal of Computer Information System, 45, 1, pp. 69-76.

Locke, E. A. (1976) 'The nature and causes of job satisfaction', in M. D. Dunnette (ed), Handbook of industrial and organizational psychology, Rand McNally, Chicago.

Lok, P. and Crawford, J. (1999) The relationship between commitment and organizational 
culture, subculture, leadership style, and job satisfaction in organizational change and development, Leadership \& Organizational Development Journal, 20, 7, pp. 365-373.

Long, D. W. and Fahey, L. (2000) Diagnosing cultural barriers to knowledge management, Academy of Management Executive, 14, 4, pp. 113-127.

Malhotra, N., Hall, J., Shaw, M. and Oppenheim, P. (2004) Essentials of marketing research: an applied orientation, Pearson Education, Frenchs Forest, NSW.

Mancheno-Smoak, L., Endres, G. M., Potak, R. and Athanasaw, Y. (2009) The individual cultural values and job satisfaction of the transformational leader, Organization Development Journal, 27, 3, pp. 9-22.

Mowday, R., Porter, L. and Steers, R. (1982) The commitment and job tenure of new employees: some evidence of post-decisional justification, Administrative Science Quarterly, 26, pp. 597-616.

Mullins, L. J. (1996) Management and organizational behavior, $4^{\text {th }}$ ed., Pitman Publishing, UK.

Nonaka, I. (1991) The knowledge-creating company, Harvard Business Review, 69, 6, pp. 96-104.

Nonaka, I. (1994) A dynamic theory of organizational knowledge creation, Organization Science, 5, 1, pp. 14-37.

Nonaka, I. and Takeuchi, H. (1995) The knowledge creating company: how Japanese companies create the dynamics of innovation, Oxford University Press, New York.

Nunnally, J. C. (1978) Psychometric theory, $2^{\text {nd }}$ ed., McGraw-Hill, New York.

Organization for Economic Cooperation and Development (OECD) (2010) Information technology outlook 2010, OECD, Paris, viewed 20 December, 2011.

http://www.oecd-ilibrary.org/science-and-technology/oecd-information-technology-o utlook- 2010/ict-skills-and-employment_it_outlook-2010-5-en

Öztemel, E. and Arslankaya, S. (2008) Enterprise wide knowledge leverage working paper, Innovative Production Machines and Systems Conference 2008, pp. 231-238.

Peters, L. H. and O'Connor, E. J. (1980) Situational constraints and work outcomes: the influences of a frequently overlooked construct, Academy of Management Review, $\mathbf{5}$, pp. 391-397.

Petrova, K. and Medlin, D. (2009) 'Informing industry via academic research in ICT skill and capability development', in L. Al-Hakim and M. Memmola (Eds) Business Web Strategy: Design, Alignment, and Application, Information Science Reference, Hershey, pp. 26-45.

Pfeffer, J. and Sutton, R. I. (2000) The knowing doing gap: how smart companies turn knowledge into action, Harvard Business School Press, Boston, MA. 
Postman, J. (2009) SocialCorp: social media goes corporate, New Riders, Berkeley, CA.

Poulin, D. and Tran, S. (2010) Information and communication technology and small and medium sized enterprises: from theory to practice, Cambridge Scholars Publishing, Newcastle upon Tyne, UK.

Rehman, M., Mahmood, A. K. B., Salleh, R. and Amin, A. (2010) International conference on e-business, management and economics, IPEDR, 3, IACSIT Press, Hong Kong.

Rikowski, R. (2007) Knowledge management: social, cultural and theoretical perspectives, Chandos Publishing, Oxford, England.

Ruppel, C. P. and Harrington, S. J. (2001a) Causal ambiguity, barriers to imitation, and sustainable competitive advantage, European Management Journal, 22, 6, pp. 714-724.

Salancik, G. R. and Pfeffer, J. (1977) An examination of need-satisfaction models of job attitudes, Administrative Science Quarterly, 22, pp. 427-456.

Schein, E. H. (2004) Organizational culture and leadership, $3^{\text {rd }}$ ed., Jossey-Bass, San Francisco

Simonin, B. L. (1999) Transfer of marketing know-how in international strategic alliances: an empirical investigation of the role and antecedents of knowledge ambiguity, Journal of International business Studies, 30, 3, pp. 463-490.

Silverthorne, C. (2004) The impact of organizational culture and person-organization fit on organizational commitment and job satisfaction in Taiwan, Leadership \& Organizational Development Journal, 30, 4, pp. 186-201.

Small, C. T. and Sage, A. P. (2006) Knowledge management and knowledge sharing: a review, Information Knowledge Systems Management, 5, 3, pp. 153-69.

Smith, P. B. (2002) Culture's consequences: something old and something new, Human Relations, 55, 2, pp. 119-135.

Smith, P. C., Kendall, L. M. and Hulin, C. L. (1969) Measurement of satisfaction in work and retirement, Rand McNally, Chicago.

Sowa, J. (1984) Conceptual structures, Addison- Wesley, Reading, Mass.

Spector, P. E. (1997) Job satisfaction: application, assessment, cause, and consequences, Sage Publications, Thousand Oaks, CA.

Steers, R. M., Sanchez-Runde, C. J. and Nardon, L. (2010) Management across cultures: challenges and strategies, Cambridge University Press, Cambridge, UK.

Steven, C. (1989) Postmodernist culture: an introduction to theories of the contemporary, Blackwell, Oxford, UK.

Straub, D., Loch, K., Evaristo, R., Karahanna, E. and Srtie, M. (2002) Toward a theory-based 
measurement of culture, Journal of Global Information Management, 10, 1, pp. $13-23$.

Syed-Ikhsan, S. and Rowland, F. (2004) Knowledge management in public organizations: a study on the relationship between organizational elements and the performance of knowledge transfer, Journal of Knowledge Management, 8, 2, pp. 95-111.

Tata, J. and Prasad, S. (1998) Cultural and structural constraints on total quality management implementation, Total Quality Management, 9, 8, pp.703-710.

Teece, D. (1998) Capturing value from knowledge assets: the new economy, markets for know-how and intangibles assets, California Management Review, 40, 3, pp. 55-79.

Torraco, R. and Swanson, R. (1996) The strategic roles of human resource development, Human Resource Planning, 18, pp. 10-21.

Tremblay, M., Sire, B. and Dalkin, D. B. (2000) The role of organizational justice in pay and employee benefit satisfaction, and its effects on work attitudes, Group and Organization Management, 25, pp. 269-290.

Trompenaars, F. (1998) Riding the waves of culture: understanding diversity in global business, $2^{\text {nd }}$ ed., McGraw-Hill, New York.

Turban, E. (1992) Expert system and applied artificial intelligence, Macmillan Publishing, New York.

Tutuncu, O. and Kozak, M. (2007) An investigation of factors affecting job satisfaction, International Journal of Hospitality \& Tourism Administration, 8, 1, pp. 1-19.

Ulrich, D. (1998) A new mandate for human resources, Harvard Business Review, 76, 1, pp. 124-139.

United Nations Conference on Trade and Development Information Economy Report (UNCTAD) (2010) ICTs, enterprises and poverty alleviation, United Nations publication, New York and Geneva.

Van den Hooff, B. and De Ridder, J. A. (2004) Knowledge sharing in context: the influence of organisational commitment, communication climate and CMC use on knowledge sharing, Journal of Knowledge Management, 8, 6, pp. 117-130.

Warr, P. (2007) Searching for happiness at work, The Psychologist, 20, 12, pp. 726-729.

Wenger, E. C. and Snyder, W. M. (2000) Communities of practice: the organizational frontier, Harvard Business Review, 78, 1, pp. 139-145.

Wiig, K. M. (1989) Managing knowledge: a survey of executive perspectives, Schema Press, Arlington, TX.

Witt, L. A., Andrews, M. C. and Kacmar, K. M. (2000) The role of participation in decision-making in the organizational politics-job satisfaction relationship, Human Relations, 53, 3, pp. 341-358. 
Yang, J. T. (2007) Knowledge sharing: investigating appropriate leadership roles and collaborative culture, Tourism Management, 28, 2, pp. 530-543.

Zahra, S. A., Neubaum, D. O. and Larraneta, B. (2007) Knowledge sharing and technological capabilities: the moderating role of family involvement, Journal of Business Research, 60, 10, pp. 1070-1079.

\section{Copyright Disclaimer}

Copyright reserved by the author(s).

This article is an open-access article distributed under the terms and conditions of the Creative Commons Attribution license (http://creativecommons.org/licenses/by/3.0/). 